\title{
Do Chinese Extraction (Mining, Oil \& Gas) Activities in Africa Overlap with Areas of Conservation Value?
}

\author{
By Douglas Scott \\ Conservation International, London
}

In December of 2010 a Washington based environmental non-government organisation (NGO) Conservation International (Cl) commissioned a desktop study on Chinese mining, oil and gas extraction operations in Africa. The report assessed whether Chinese extraction operations were located in and/or adjacent to areas of conservation value. This summery of that report will only give a brief outline of issues that concern $\mathrm{Cl}$ and other environmental NGOs and will instead focus on a summary of the findings on Chinese extraction operations.

The report focuses on extraction operations in eleven African countries where $\mathrm{Cl}$ has a significant presence and/ or interest. ${ }^{1} \mathrm{Cl}$ aimed to establish whether to initiate partnerships with specific Chinese companies in the extraction industry that were similar to some of the partnerships it had already developed with western mining, oil \& gas companies. ${ }^{2}$

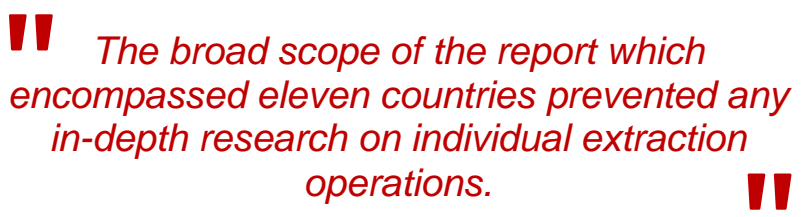

Cl's Integrated Biodiversity and Assessment Tool (IBAT) ${ }^{3}$ was used to compile the country specific maps and determine the location of Chinese extraction operations in relation to biologically sensitive areas. An IBAT map similar to the Zambian map was done for each of the eleven countries. An example of one of these maps can be found on figure 2 which looks at Zambia.

The broad scope of the report which encompassed eleven countries ${ }^{4}$ prevented any indepth research on individual extraction operations. Only Chinese owned operations directly involved in the extraction process were investigated. Exploration, prospecting and beneficiation operations were not included in this report. Only well-established operations with over US $\$ 10$ million in Chinese investment were included in the report. ${ }^{5}$

\section{Magnitude of investments}

Figure 1 depicts the countries investigated (as highlighted in red on the map) and the location of some significant Chinese extraction operations (both publicly and privately owned) ${ }^{6}$ which are further described in the report.

Many of these operations are joint ventures between either western mining houses (predominantly Australian) or local African State-Owned Enterprises (SOE). 


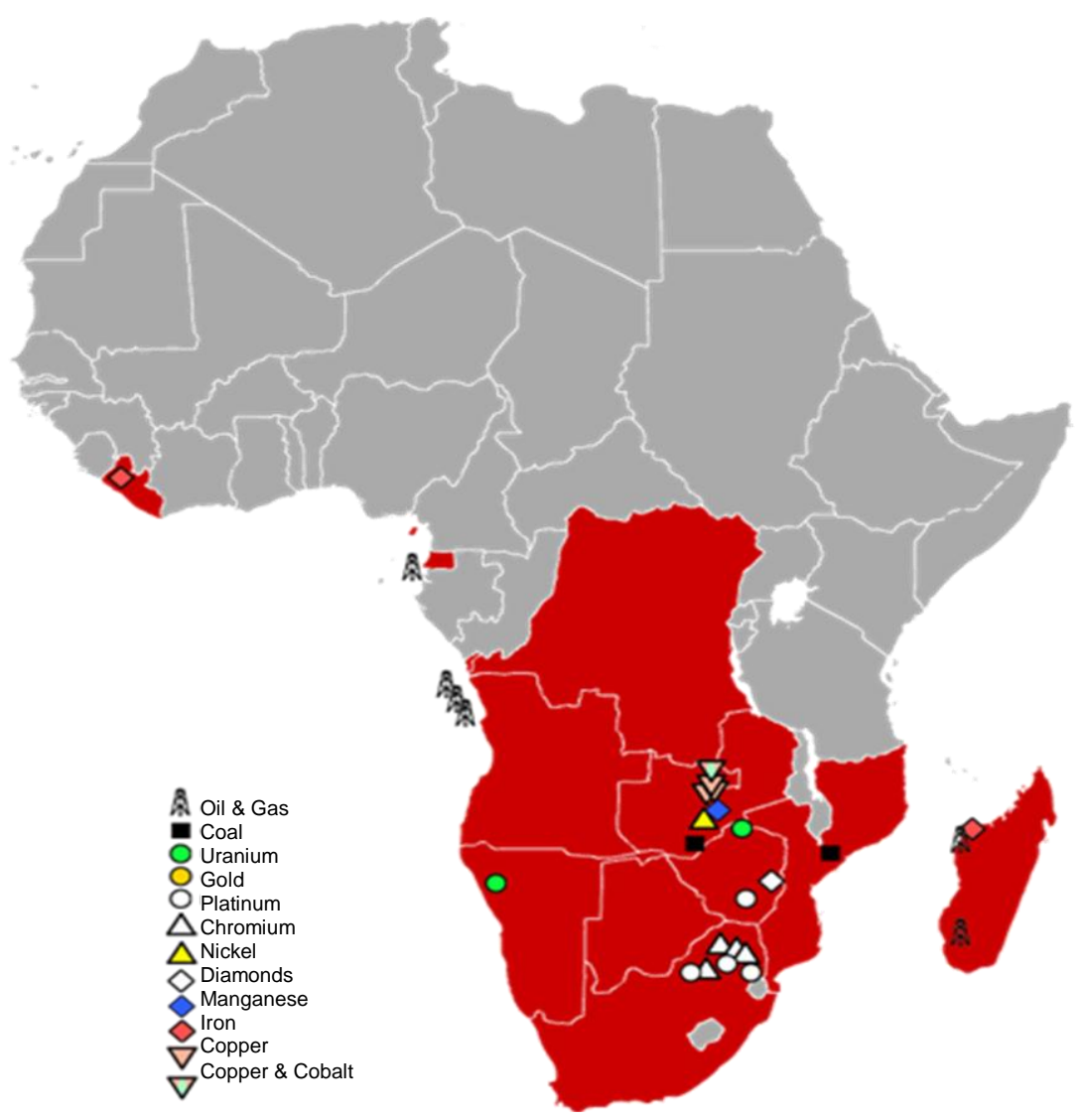

Source: (Scott; 2011: 24)

The most noticeable finding was just how small China's presence actually is in the eleven countries investigated; both in relation to people's perceptions of the extent of Chinese investments in the extraction sector and in relation to the scale of Western investments. Although the number of Chinese extraction operations is relatively small in proportion to popular perception it is large for any single country and growing rapidly.

\section{The concentration of Chinese extraction operations and investments appear to be primarily in South Africa and Zambia.}

Whilst the larger deals are substantial they are a minority of Chinese owned mining operations. At a meeting with the Financial Director of Sinosteel in Sandton (Johannesburg, South Africa) it was explained to Cl that Sinosteel Pty Ltd (which comprises 86 companies, 23 of which are outside China) does not have the time or expertise to get involved in actual mining and prefers to buy shares in large existing mining companies so that the resources can be traded and sent to China quickly based on the current demand.

The concentration of Chinese extraction operations and investments appear to be primarily in South Africa and Zambia. While Zambia has a long history of Chinese investment in the mining sector (particularly in copper) and an even longer relationship on the international stage South Africa recognized the People's 
Republic of China only in 1998. South Africa does have large chrome and platinum group metals deposits both of which are of great value for Chinese industry. South Africa also has well developed legal and financial institutions that mitigate risk for Chinese investors and increase the ease of investing in the country. Additionally most of the already established and fully functional extraction operations are located in Zambia and South Africa whereas the majority of the extraction operations underway in the other countries looked at are not yet online.

It must however be noted that Chinese investors (both SOE and private) are greatly expanding their investments in African resources. This is particularly true for energy and ferrous metals. One factor driving the interest in ferrous metals has been a desire to expand and acquire more overseas iron ore reserves to reduce China's reliance on imports from foreign firms. ${ }^{7}$ This was partly catalysed by an incident in July 2009 when Australian mining giant Rio Tinto was accused by the Chinese government of fixing Chinese iron ore prices and thereby increasing the cost of processed iron products so reducing the country's competitive edge in the manufacturing sector. ${ }^{8}$

A possible manifestation of this drive to secure additional mineral reserves is an apparent prospecting boomcurrently taking place across southern Africa. Preliminary observations are that it is being driven by Chinese companies seeking to find and/or buy up as yet unfound deposits that have not yet been secured by western mining houses. ${ }^{9}$

\section{Structure of investments}

The structure of Chinese investments in the mining, oil and gas extraction sector can be divided into two groups, wholly owned and joint ventures. With wholly owned operations tending to be the preferred structure of privately owned operations by Chinese nationals. Joint-ventures tend to be the preferred investment structure of larger and more professionally run state owned enterprises (SOE).

Often these have been done between a number of Chinese partner organisations in addition to the non-Chinese partner. Sometimes involving one (or in larger cases more) Chinese mining and/or beneficiation companies (usually SOEs) and a financing institution (often the China Africa Development fund or EXIM Bank of China) in addition to the non-Chinese partner. The non-Chinese partner is required for a number of reasons including ranging from their access to existing mining rights that the Chinese are interested in to utilising advanced technical mining/extraction skills (often by western firms) such is the case with off shore oil extraction in Angola. In return for the necessary equipment, technical training and financing Chinese producers get a secure source of important raw materials.

\section{Much of Chinese SOE's preference for joint- ventures in extraction operations in Africa can be explained by China's own foreign investment and development experience with Japan.}

Much of Chinese SOE's preference for joint-ventures in extraction operations in Africa can be explained by China's own foreign investment and development experience with Japan in the 1970 s and early 1980 s. $^{10}$ It is therefore a model that they have a comfortable degree of experience with and which worked well for China when the country was in a similar developmental position as much of Africa is today. 


\section{Environmental Impact}

By and large corporate social responsibility (CSR) policies of Chinese companies today are in a similar state to the CSR policies of western companies in the mid1990s. Whilst pressure for western companies to improve their environmental policies has largely come from NGOs and civil society, for Chinese firms this pressure comes from government which in turn is influenced by popular opinion.

Although there is growing awareness and an increasing interest in CSR and environmental impact mitigation policies by Chinese companies operating outside China there is still considerable room for improvement with regards to how these companies address environmental issues associated with their extraction activities.

Most of the time mining firms are unaware of the biodiversity in the area that they are operating in. This is as true for Chinese firms as it is for firms from other countries. By overlaying the locations of extraction operations onto maps compiled using IBAT ${ }^{11}$ it is possible to determine the position of Chinese extraction operations in relation to their proximity to biologically sensitive areas. An example of this is given in figure $2^{12}$ which illustrates the position of extraction operations with a significant level of Chinese ownership in relation to biodiversity areas in Zambia.

Figure 2: Main mining operation areas and biodiversity hotspots in Zambia

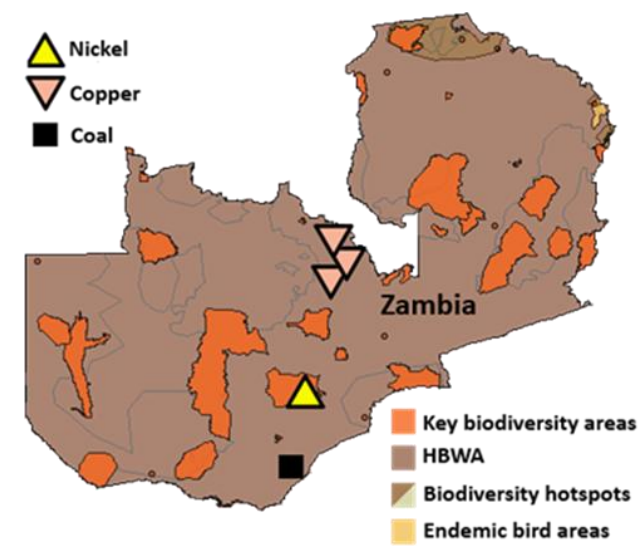

Source: (Scott; 2011: 39)

A table charting the biodiversity areas across the eleven African countries that the 27 projects looked are located in can be found in figure 3. Apart from the operations located in High Biodiversity Wilderness Areas ${ }^{13}$-which is largely unavoidable due to the vast areas of Southern Africa covered by this area type- most of the operations looked at are located in areas that are not particularly sensitive. A few notable exceptions are the larger iron ore mines being opened up in Liberia (Bong Mine) and Madagascar (Soalala iron ore project).

\section{Looking forward}

For environmental organisations - whether from the western world, Africa or Chinathere is clearly space to work with Chinese firms engaged in extraction activities outside of China. Chinese extraction firms are increasingly aware of the need to 
improve their environmental record. Space for partnerships with environmental groups that could produce mutually beneficial outcomes (for both the relevant firm and the local environment) does exist. However significant challenges in terms of setting up these relationships would need to be overcome and only relationships that fully include local African governments would stand the best chance of success.

\section{II \\ Chinese extraction firms are increasingly aware of the need to improve their \\ environmental record. \\ II}

Chinese extraction firms often rely on the guidelines of the country they are operating in. If these guidelines are lacking or less robust then environmental guidelines in China then Chinese firms tend to use Chinese guidelines as their standard. This means that so far as environmental standards are concerned room for greater improvement in such guidelines and their proper implementation in an African context is largely reliant on African governments. From the point of view of African governments balancing the needs of the environment with the need for investment and development is a tricky issue. This must also be taken into account.

Figure 3: Biodiversity location table for 27 Chinese operations in Africa

\begin{tabular}{|c|c|c|c|c|c|}
\hline & $\begin{array}{c}\text { Key } \\
\text { Biodiversity } \\
\text { Areas }\end{array}$ & $\begin{array}{c}\text { Biodiversity } \\
\text { Hotspots }\end{array}$ & HBWA & $\begin{array}{c}\text { Endemic } \\
\text { Bird Areas }\end{array}$ & None \\
\hline $\begin{array}{c}\text { Key } \\
\text { Biodiversity } \\
\text { Areas }\end{array}$ & NA & & & 4 & 1 \\
\hline $\begin{array}{c}\text { Biodiversity } \\
\text { Hotspots }\end{array}$ & 2 & NA & & 1 & \\
\hline HBWA & 2 & NA & 1 & 8 \\
\hline $\begin{array}{c}\text { Endemic Bird } \\
\text { Areas }\end{array}$ & & & & NA & 3 \\
\hline None & & & & & 7 \\
\hline
\end{tabular}

Source: Author

\section{End Notes}

${ }^{1}$ It is important to emphasise that non-extraction related mining activities such as beneficiation were not looked at in the report. However for the interested reader a list of thirteen Chinese, mostly privately owned, beneficiation operations in the DRC are listed on pages 48-49.

${ }^{2}$ Smuts, Rowena (February 2010), "Are partnerships the key to conserving Africa's biodiversity?", Conservation International: Washington D.C., Available at: http://www.cbd.int/impact/case-studies/cs-impact-USAID-africa-mining-conservationen.pdf

${ }^{3}$ Integrated Biodiversity and Assessment Tool, Available at: https://www.ibatforbusiness.org

${ }^{4}$ The eleven Africa countries looked at were Angola, Botswana, Equatorial Guinea, Liberia, Madagascar, Mozambique, Namibia, South Africa, Zambia, Zimbabwe and 
the Democratic Republic of the Congo.

${ }^{5} \mathrm{~A}$ few notable exceptions were made largely on either the lack of other significant Chinese owned extraction operations in that country or the seeming certainty of the near completion of a large deal.

${ }^{6}$ Amendment: The original report also includes the Grootvlei and Orkney gold mines which at the time of the completion of the report it appeared that these mines would soon be sold to Shandong Gold and as such were worthy of mention. However this deal has since fallen through.

${ }^{7}$ Minmetals to buy more assets (2 March 2011), by Zhang Qi, China Daily:Beijing, Available at: http://www.chinadaily.com.cn/business/201103/02/content 12100636.htm, Retrieved: 12 March 2011.

${ }^{8}$ The Rio Tinto case in the Chinese media (13 August 2009), by lacob Koch-Weser, Danwei, Available at:

http://www.danwei.org/media/chinese media on the rio tinto.php, Retrieved: 12 March 2011.

${ }^{9}$ Scott, Douglas (2011), "Do Chinese Extraction (Mining, Oil \& Gas) Activities in Africa Overlap with Areas of Conservation Value?", Conservation International, pg13, 30.

${ }^{10}$ As Deborah Brautigam most recently noted in both her book (The Dragon's Gift: The Real Story of China in Africa (2009): 47) and at a recent U.S. Senate Committee hearing. Available at:http://foreign.senate.gov/hearings/hearing/?id=8651beb7-5056a032-52db-ffb33c635619

${ }^{11}$ The IBAT analysis focused on four main variables. They are Key Biodiversity Areas, Biodiversity Hotspots, High Biodiversity Wilderness Area and Endemic Bird Areas. An expanded definition of these variables can be found in the report or on IBATs website. Available at: https://www.ibatforbusiness.org/data behind ibat

${ }^{12}$ Two notes on the Zambia map (Figure 2):

- No. 5 - The Kabwe Nickel mine was shutdown in 2007 due to excessively high levels of pollution produced by the mine

- No. 3 - the Mpongwe copper mine is still in the start-up stage but a number of sites have been confirmed hence its addition to the report.

${ }^{13}$ Definition: Large areas of at least $10,00 \mathrm{~km} 2$ in size and consisting of regions that have a relatively undisturbed environment that is at least $70 \%$ intact. In addition these areas also have $a$ at least 1,500 endemic plant species. These three factors combined form a supplementary broad-scale priority to biodiversity hotspots for Conservation international.

\section{References}

Scott, Douglas. 2011. Do Chinese Extraction (Mining, Oil \& Gas) Activities in Africa Overlap with Areas of Conservation Value? Conservation International. Online: [here], Accessed: 3 March 2011.

Douglas Scott is an analyst and a former research intern for Conservation International. He completed his Masters degree in public management and Chinese economic development policy at Tsinghua University where he also

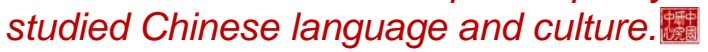

